International Journal of Environment, Agriculture and Biotechnology
Vol-6, Issue-4; Jul-Aug, 2021
JUAB
Journal Home Page Available:https://ijeab.com/
Journal DOI: $10.22161 /$ ijeab

\title{
Effect of Physico-chemical properties of water on population of Macrozoobenthos of Kunghada Bandh Lake, Dist.- Gadchiroli, Maharashtra (India)
}

\author{
Rajendra V. Tijare ${ }^{1 *}$, Gurudeo E. Kunghadkar ${ }^{2}$ \\ ${ }^{1}$ Department of Zoology, Institute of Science, R.T. Road, Civil Lines, Nagpur, India. \\ ${ }^{2}$ Government Medical College, Chandrapur, India. \\ *Corresponding Author
}

Received: 08 Jul 2021; Received in revised form: 02 Aug 2021; Accepted: 10 Aug 2021; Available online: 19 Aug 2021

C2021 The Author(s). Published by Infogain Publication. This is an open access article under the CC BY license

(https://creativecommons.org/licenses/by/4.0/).

\begin{abstract}
Correlation study of physicochemical properties with biota of any fresh water body depicts the status of any ecosystem. Correlation of physicochemical parameters with benthic organisms especially macrozoobenthos of Kunghada Bandh Lake was organized to know the status of this fresh water ecosystem. This type of study is very useful to calculate the quality of water and restoration of such type of fragile ecosystem time to time. Samples were collected from five different sampling stations for two years i.e. from February 2012 to January 2013 and February 2013 to January 2014. Macrozoobenthos were collected from all five stations by using 'Ekman's dredge' and 'Van-Vin grab'. Annelids observed more in monsoon and winter than summer. Total 09 species of arthropods were recorded. Minimum average of Arthropods was recorded in summer and maximum average of Arthropods in monsoon. The same trend was followed by molluscan species. The increased concentrations of most of the chemical parameters in summer affects on the population of most of the faunal component in decreased manner.
\end{abstract}

Keywords-Physico-chemical, Population, Macrozoobenthos, Kunghada bandh.

\section{INTRODUCTION}

The study of hydrobiology means relation between water and living thing i.e. micro and macro organisms present in aquatic ecosystems (Chatwal G.R.,1996). Kunghada Bandh Lake (latitude $20.22^{\circ} \mathrm{N}$ and longitude $80.01^{\circ} \mathrm{E}$.) is constructed by British Government in 1890 present in Chamorshi Tahsil of Gadchiroli district which is easternmost part of Maharashtra state of India. Lake having area near about $5.95 \mathrm{sq}$. km. occupying water capacity 3.017 cubic density while the useful water storage is about 2.844 cubic density. It is the huge lake and having water spread area about 34.70 hectare. Perimeter of the lake is 1372 meter having main canal of 8.96 kilometer in length. This study is organised for the determination of correlation and effect of physicochemical parameters on population of benthic organisms especially macrozoobenthos of the lake. This type of study is always useful to maintain fair quality of water and restoration of such type of fragile ecosystem time to time.

The physico-chemical and biological factors affect the quality of water according to their characteristics and nature.

Benthic organisms or zoobenthos is the group of community of an organisms which live on, in or near the shore of water body, this zone is also known as profundal zone or benthic or bottom zone. Zoobenthos generally cannot survive in the upper parts of the water column due to the pressure difference between the lower and upper parts of the water column. The food chains of most of the benthic organisms are comprises dead and decaying matter and most of them are detrivores in nature. The main food sources of these organisms are planktons, algae and other organic runoff that comes from catchment area of lake. Various physic-chemical and biological factors play an 
important role in the presence or absence of benthic organisms in any aquatic ecosystem. For this correlation study; macrobenthos having size more than 1 milimeter or 1,000 micrometer $(\mu \mathrm{m})$ were taken in to consideration.

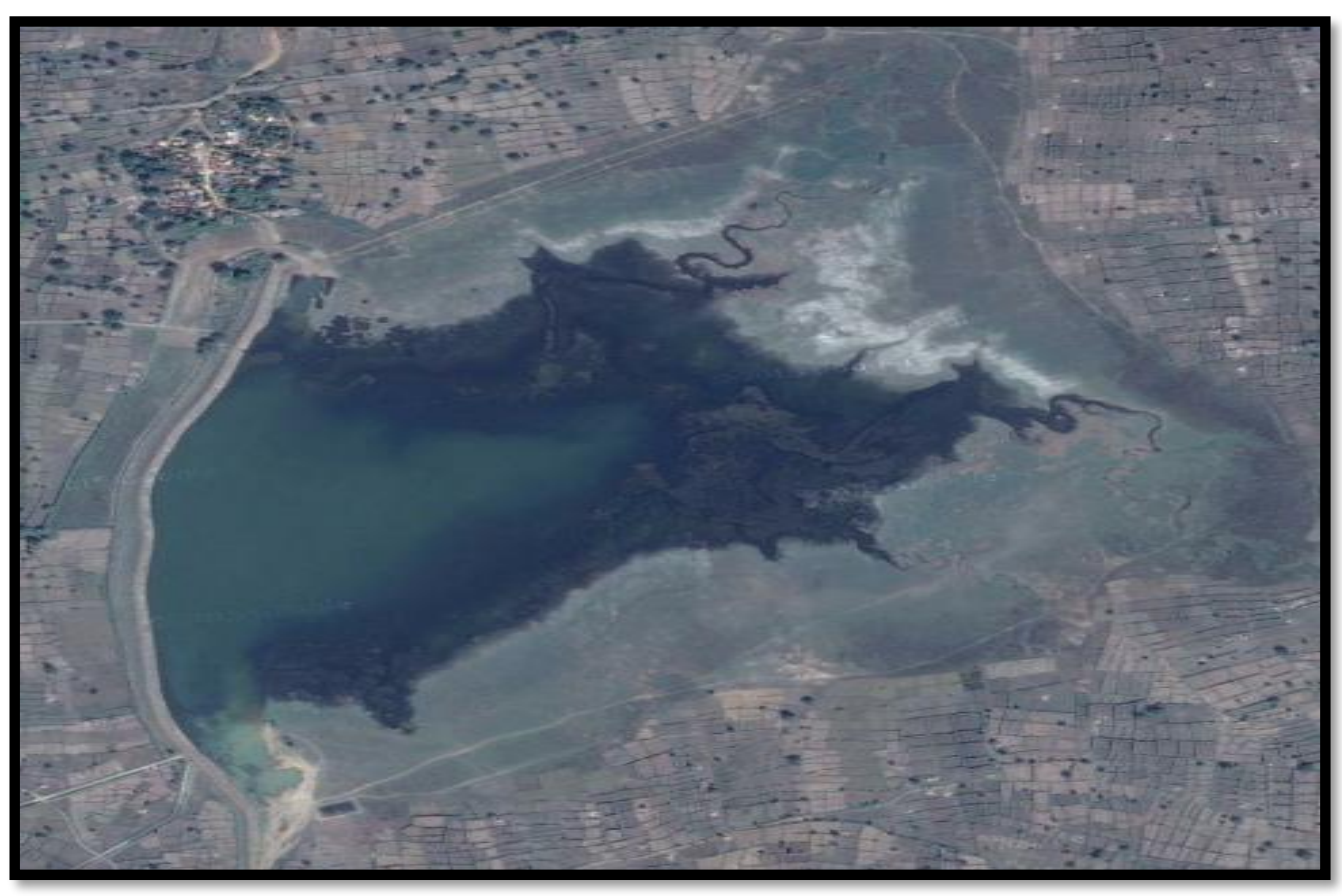

Fig. 1:Satellite image of 'Kunghada Bandh' (Curtsy: Google map)

\section{MATERIAL AND METHODS}

The water samples and macrozoobenthos were collected from five different stations covering East, West, North, South and Centre part of lake. The water samples collected in a plastic can from each station and immediately analysed in the laboratory. Some parameters were analysed on the spot such as temperature, $\mathrm{pH}$, dissolved oxygen, etc. by using titrometric mobile test water kit and digital devices. The macrozoobenthos were collected from all five stations in white enamel tray by using 'Ekman's dredge' and 'Van-Vin grab'.

The samples were collected every month during morning period two years i.e. February 2012 to January 2014 and categorized them according different species. During the investigation various parameters like physical, chemical and biological were taken into consideration for correlation study.

The analyses of all collected samples were determined by as per available and prescribed standard methods(AWWA , APHA ,2005, Santhanam et.al., 1989, Trivedi R.K. and Goel P.K., 1984,Welch P.S.,1952). The collected macrozoobenthos were segregated and identified according to different phylum up to species level with the help of various standard keys (Needham J.G.,1962 and Tonapi G.T., 1980). The densities of macrozoobenthos were calculated by using the following formula.

$$
\mathrm{N} / \mathrm{M}^{2}=\frac{n \times 10^{4}}{A}
$$

Where,

$\mathrm{N}=$ Total No. of organisms (actual count of particular species in its residing habitat)

$n=$ No. of organisms per sample (actual count of particular species per dredge)

$\mathrm{A}=$ Area of the sampler (6" X 6" X 6").

\section{RESULT AND DISCUSSION}

\section{Physico- chemical parameters:}

Most of the physico-chemical factors affect the quality of water which results in fluctuation in frequency of benthic organisms (BIS.,2012).

The minimum average of temperature (22.38, \pm 0.92 ) was recorded in winter and maximum average of temperature $(25.98, \pm 1.56)$ in summer as compared to the annual average of temperature $(24.73, \pm 2.03)$. Temperature mostly increases during summer and declines during winter because of atmospheric temperature are highest in summer and winter has lowest (Dubey M.A. et.al., 2013, Rajanna A.H. and Belagalli S.L., 2011),). During the study, temperature recorded lowers in winter and more in summer.

$\mathrm{pH}$ is the most important factor in water both for flora and fauna. The acceptable limit of $\mathrm{pH}$ in drinking 
water should be in the range of 6.5 to 8.5 (BIS, 2012). The minimum average $\mathrm{pH}(7.67, \pm 0.17)$ was recorded in monsoon while maximum average $\mathrm{pH}(8.11, \pm 0.11)$ in summer as compared to the annual average of $\mathrm{pH}$ $(7.94, \pm 0.65)$. It occurs might be due to the when photosynthesis uses up dissolved $\mathrm{CO}_{2}$, which acts like carbonic acid. Carbon dioxide removal, in effect reduces the $\mathrm{pH}$ of water.

Total solids (mg/lit.) are equal to the suspended solids plus total dissolved solids. Minimum average of total solids $(78.25, \pm 4.49)$ was recorded in winter and maximum average of total solids $(102.25, \pm 6.27)$ in summer as compared to the annual average of total solids $(93.42, \pm 12.92)$. Total dissolved solids (mg/lit) comprise inorganic salts and some small amounts organic matter which are dissolved in water. The acceptable limit of Total dissolve solids in drinking water should not be more than $500 \mathrm{mg} / \mathrm{l}$ (BIS, 2012). The minimum average of total dissolved solids $(60.88, \pm 4.88)$ was recorded in winter and maximum average of total dissolved solids $(81.5, \pm 5.18)$ in summer while average of total dissolved solids is $74.21, \pm 11.21$. Total dissolved solids mostly increase during summer due to increases in sedimentation and decrease in quantity of water which results in decrease in depth of water also. Suspended solids used as an indicator to check water quality. The minimum average of suspended solids $(17.37, \pm 1.56)$ was recorded in winter and maximum average of suspended solids $(20.75, \pm 1.44)$ in summer (Wilson, P.C., 2010)

Turbidity (NTU) in water is caused by suspended matter, such as silt, clay, finely divided organic and organic matter, soluble coloured organic compounds, microscopic organisms, and planktons (AWWA-APHA., 2005). The acceptable limit of Turbidity in drinking water should not be more than 1 NTU (BIS, 2012). The minimum average of turbidity $(6.3, \pm 0.25)$ was recorded in winter and maximum average of turbidity $(7.32, \pm 0.22)$ in monsoon as compared to the annual average of turbidity $(6.78, \pm 0.49)$ (Wilson, P.C., 2010).

Electrical conductivity ( $\mu$ mhos) is the measure of a material's ability to conduct or accommodate of an electric current or an electric charge. Minimum average of electrical conductivity $(95.0, \pm 5.43)$ was recorded in winter and maximum average of electrical conductivity (114.37, \pm 9.81) and annual average of electrical conductivity is $(107.46, \pm 11.29)$. Conductivity mostly increases during summer because of surface evaporation of water which results in rising of concentration of salts while decline in conductivity during in winter is due to the sedimentation and utilization of minerals by growing phytoplankton and macrophytes (Puri, P.J et.al.2010).
A high level of hardness is not health concern but still up to $80 \mathrm{mg} / \mathrm{lit}$ is standard limit for drinkable water ((AWWA-APHA., 2005). Both calcium and magnesium are very useful for plants and animals. The acceptable maximum limit of total hardness in drinking water should be $200 \mathrm{mg} / \mathrm{l}$ (BIS, 2012). Minimum average of total hardness $(63.16, \pm 2.96)$ was recorded in winter and maximum average of total hardness $(86.95, \pm 3.57)$ in summer as compared to the annual average of total hardness $(76.02, \pm 10.91)$. It might be due to high temperature in summer which results in the breakdown of rocks, less amount of water and domestic uses specially detergents (Sukund, B.N. and Patil, H.S., 2004)). Calcium is very important for the formation of bones in vertebrates and shell in molluscans. A low level of calcium in water reduces the number of fauna. Minimum calcium hardness (31.32, \pm 0.99$)$ was recorded in winter and maximum calcium hardness $(41.72, \pm 5.53)$ in summer and annual average of calcium hardness is $(37.08, \pm 5.69)$. Calcium hardness was mostly decline during winter and increases in summer in lake water (Karim L.R. et.al., 2012 and Kumar B.M. et.al., 2004). Magnesium is very important for plants to form chlorophyll; less amount of magnesium reduces the population of phytoplankton and aquatic plants. The minimum average of magnesium hardness $(31.35, \pm 2.17)$ was recorded in winter and maximum average of magnesium hardness $(45.22, \pm 5.23)$ in summer as compared to the annual average of magnesium hardness $(38.78, \pm 7.29)$. The magnesium hardness recorded less in winter because most of the magnesium is utilized by large vegetation (Shinde, S.K. et.al., 2010).

Calcium plays an important role in the maintenance of structural and functional integrity of cell membranes in ion retention and absorption of both flora and fauna (Wetzel, R.G., 1975). The acceptable limit of $\mathrm{Ca}^{++}$in drinking water should not be more than $75 \mathrm{mg} / \mathrm{l}$ (BIS, 2012). Minimum average of $\mathrm{Ca}^{++}(12.72, \pm 0.48)$ was recorded in winter and maximum average of $\mathrm{Ca}^{++}$ $(16.69, \pm 2.21)$ in summer as compared to the annual average of $\mathrm{Ca}^{++}(14.90, \pm 2.22)$. Magnesium is very important for plants to form chlorophyll; less amount of magnesium reduces the number of phytoplankton and plants. It also acts as micronutrient in enzymatic transformation, especially in algae, bacteria and fungi. Minimum average of $\mathrm{Mg}^{++}(7.52, \pm 0.52)$ was recorded in winter and maximum average of $\operatorname{Mg}^{++}(10.85, \pm 1.26)$ in summer as compared to the annual average of $\operatorname{Mg}^{++}(9.31, \pm 1.75)$. It might be due to the degradation of plants, more leaching of rocks in summer and most of the magnesium is utilized by large vegetation in monsoon and winter (Pawar S. and Sonawane S., 2011). 
Table1: Average monthly values of physico-chemical parameters during two years (Feb. 2012 to Jan. 2014)

\begin{tabular}{|c|c|c|c|c|c|c|c|c|c|c|c|c|c|c|}
\hline \multirow{2}{*}{ S.N. } & \multirow{2}{*}{ Parameters } & \multirow{2}{*}{ Unit } & \multicolumn{4}{|c|}{ Summer } & \multicolumn{4}{|c|}{ Monsoon } & \multicolumn{4}{|c|}{ Winter } \\
\hline & & & FEB & MAR & APR & MAY & JUN & JUL & AUG & SEP & OCT & NOV & DEC & JAN \\
\hline 01 & Water Temperature & ${ }^{0} \mathrm{C}$ & 24 & 25.2 & 26.5 & 28.2 & 27.1 & 26.1 & 25.5 & 24.6 & 23.85 & 22.5 & 21.5 & 21.7 \\
\hline 02 & $\mathrm{Ph}$ & .......... & 8.0 & 8.0 & 8.25 & 8.2 & 7.9 & 7.75 & 7.45 & 7.6 & 7.95 & 8.3 & 7.9 & 7.95 \\
\hline 03 & Total Solids & $\mathrm{mg} / \mathrm{lit}$ & 97 & 96.5 & 103.5 & 112 & 116 & 98 & 93.5 & 91.5 & 83 & 82 & 76 & 72 \\
\hline 04 & TDS & $\mathrm{mg} / \mathrm{lit}$ & 76 & 78 & 82.5 & 89.5 & 94 & 79 & 74 & 74 & 66 & 65.5 & 56 & 56 \\
\hline 05 & Suspended Solids & $\mathrm{mg} / \mathrm{lit}$ & 21 & 18.5 & 21 & 22.5 & 22 & 19 & 19.5 & 17.5 & 17 & 16.5 & 20 & 16 \\
\hline 06 & Turbidity & NTU & 6.45 & 6.6 & 6.7 & 7.15 & 7.2 & 7.65 & 7.4 & 7.05 & 6.7 & 6.3 & 6.15 & 6.05 \\
\hline 07 & Elect. Cond. & $\mu \mathrm{mhos}$ & 102 & 110.5 & 116 & 129 & 120.5 & 113.5 & 110.5 & 107.5 & 103 & 96 & 88 & 93 \\
\hline 08 & Total Hardness & $\mathrm{mg} / \mathrm{lit}$ & 81.85 & 85.65 & 88.95 & 91.35 & 86.5 & 81.4 & 76 & 67.95 & 63.9 & 60.6 & 60.45 & 67.7 \\
\hline 09 & $\mathrm{Ca}$ - Hardness & $\mathrm{mg} / \mathrm{lit}$ & 38.55 & 44.35 & 34.75 & 49.25 & 38 & 41.2 & 40.4 & 33.15 & 32.5 & 31.9 & 29.85 & 31.05 \\
\hline 10 & Mg - Hardness & $\mathrm{mg} / \mathrm{lit}$ & 43.3 & 41.3 & 54.2 & 42.1 & 48.5 & 40.2 & 35.6 & 34.8 & 31.4 & 28.7 & 30.6 & 34.7 \\
\hline 11 & Calcium- $\left(\mathrm{Ca}^{++}\right)$ & $\mathrm{mg} / \mathrm{lit}$ & 15.42 & 17.74 & 13.9 & 19.7 & 15.2 & 16.48 & 16.16 & 13.26 & 13 & 12.76 & 11.94 & 13.2 \\
\hline 12 & Magnesium- $\left(\mathrm{Mg}^{++}\right)$ & $\mathrm{mg} / \mathrm{lit}$ & 10.39 & 9.91 & 13.01 & 10.1 & 11.64 & 9.65 & 8.54 & 8.35 & 7.54 & 6.89 & 7.34 & 8.33 \\
\hline 13 & Dissolved Oxygen & $\mathrm{mg} / \mathrm{lit}$ & 5.7 & 5.8 & 5.8 & 5.55 & 6.0 & 6.3 & 6.55 & 6.8 & 6.4 & 6.55 & 5.95 & 5.85 \\
\hline 14 & Free $\mathrm{CO}_{2}$ & $\mathrm{mg} / \mathrm{lit}$ & 5.8 & 5.9 & 6.2 & 6.6 & 6.05 & 5.6 & 5.5 & 5.2 & 5.3 & 5.2 & 4.75 & 4.9 \\
\hline 15 & Alkalinity & $\mathrm{mg} / \mathrm{lit}$ & 68.1 & 72.35 & 74.25 & 75.95 & 76.3 & 71.6 & 68.35 & 64.65 & 58.95 & 58.65 & 57.25 & 59.4 \\
\hline 16 & Acidity & $\mathrm{mg} / \mathrm{lit}$ & 5.65 & 5.3 & 5.0 & 4.7 & 4.5 & 4.25 & 4.3 & 4.05 & 3.8 & 3.6 & 3.4 & 4.0 \\
\hline 17 & Phosphate & $\mathrm{mg} / \mathrm{lit}$ & 0.68 & 0.79 & 0.92 & 1.09 & 1.92 & 1.41 & 1.13 & 0.09 & 0.07 & 0.12 & 0.085 & 0.17 \\
\hline 18 & Nitrate & $\mathrm{mg} / \mathrm{lit}$ & 0.21 & 0.285 & 0.39 & 0.56 & 0.68 & 0.98 & 0.98 & 1.11 & 1.04 & 0.64 & 0.22 & 0.25 \\
\hline 19 & Sulphate & $\mathrm{mg} / \mathrm{lit}$ & 18.75 & 20.1 & 21.75 & 22.4 & 22.8 & 23.1 & 20.85 & 19.4 & 17.8 & 17.15 & 16.65 & 17.35 \\
\hline 20 & Chloride & $\mathrm{mg} / \mathrm{lit}$ & 4.7 & 4.5 & 4.6 & 5.3 & 5.9 & 6.7 & 6.8 & 6.9 & 7.1 & 6.35 & 6.0 & 6.25 \\
\hline
\end{tabular}


Table 2: Average annual and seasonal values of physico-chemical parameters during two years (Feb. 2012 to Jan. 2014)

\begin{tabular}{|c|c|c|c|c|c|c|c|c|c|c|c|c|}
\hline \multirow{2}{*}{ S.N. } & \multirow{2}{*}{ Parameters } & \multirow{2}{*}{ Unit } & \multicolumn{4}{|c|}{ Annual } & \multirow{2}{*}{$\begin{array}{c}\text { Summer } \\
\text { Avg. }\end{array}$} & \multirow{2}{*}{$\begin{array}{c}\text { Summer } \\
\text { SD }\end{array}$} & \multirow{2}{*}{$\begin{array}{c}\text { Monsoon } \\
\text { Avg. }\end{array}$} & \multirow{2}{*}{$\begin{array}{c}\text { Monsoon } \\
\text { SD }\end{array}$} & \multirow{2}{*}{$\begin{array}{r}\text { Winter } \\
\text { Avg. }\end{array}$} & \multirow{2}{*}{$\begin{array}{r}\text { Winter } \\
\text { SD }\end{array}$} \\
\hline & & & Min & Max & Avg. & SD & & & & & & \\
\hline 1 & Water Temperature & ${ }^{0} \mathrm{C}$ & 21.5 & 28.2 & 24.72 & 2.02 & 25.97 & 1.55 & 25.82 & 0.90 & 22.38 & 0.92 \\
\hline 2 & $\mathrm{pH}$ & $\ldots \ldots \ldots$ & 7.45 & 8.3 & 7.93 & 0.24 & 8.11 & 0.11 & 7.67 & 0.16 & 8.02 & 0.16 \\
\hline 3 & Total Solids & $\mathrm{mg} / \mathrm{lit}$ & 72 & 116 & 93.41 & 12.92 & 102.25 & 6.26 & 99.75 & 9.67 & 78.25 & 4.49 \\
\hline 4 & TDS & $\mathrm{mg} / \mathrm{lit}$ & 56 & 94 & 74.20 & 11.33 & 81.5 & 5.18 & 80.25 & 8.19 & 60.87 & 4.87 \\
\hline 5 & Suspended Solids & $\mathrm{mg} / \mathrm{lit}$ & 16 & 22.5 & 19.20 & 2.07 & 20.75 & 1.43 & 19.5 & 1.62 & 17.37 & 1.55 \\
\hline 6 & Turbidity & NTU & 6.05 & 7.65 & 6.78 & 0.48 & 6.72 & 0.26 & 7.32 & 0.22 & 6.3 & 0.24 \\
\hline 7 & Elect. Cond. & $\mu$ mhos & 88 & 129 & 107.45 & 11.29 & 114.37 & 9.80 & 113 & 4.82 & 95 & 5.43 \\
\hline 8 & Total Hardness & $\mathrm{mg} / \mathrm{lit}$ & 60.45 & 91.35 & 76.02 & 10.91 & 86.95 & 3.57 & 77.96 & 6.87 & 63.16 & 2.96 \\
\hline 9 & $\mathrm{Ca}$ - Hardness & $\mathrm{mg} / \mathrm{lit}$ & 29.85 & 49.25 & 37.07 & 5.69 & 41.72 & 5.52 & 38.18 & 3.13 & 31.32 & 0.99 \\
\hline 10 & Mg - Hardness & $\mathrm{mg} / \mathrm{lit}$ & 28.7 & 54.2 & 38.78 & 7.28 & 45.22 & 5.23 & 39.77 & 5.44 & 31.35 & 2.16 \\
\hline 11 & Calcium- $\left(\mathrm{Ca}^{++}\right)$ & $\mathrm{mg} / \mathrm{lit}$ & 11.94 & 19.7 & 14.89 & 2.21 & 16.69 & 2.21 & 15.27 & 1.25 & 12.72 & 0.47 \\
\hline 12 & Magnesium- $\left(\mathrm{Mg}^{++}\right)$ & $\mathrm{mg} / \mathrm{lit}$ & 6.89 & 13.01 & 9.30 & 1.74 & 10.85 & 1.25 & 9.54 & 1.30 & 7.52 & 0.52 \\
\hline 13 & Dissolved Oxygen & $\mathrm{mg} / \mathrm{lit}$ & 5.55 & 6.8 & 6.10 & 0.38 & 5.71 & 0.10 & 6.41 & 0.29 & 6.18 & 0.29 \\
\hline 14 & Free $\mathrm{CO}_{2}$ & $\mathrm{mg} / \mathrm{lit}$ & 4.75 & 6.6 & 5.58 & 0.52 & 6.12 & 0.31 & 5.58 & 0.30 & 5.03 & 0.22 \\
\hline 15 & Alkalinity & $\mathrm{mg} / \mathrm{lit}$ & 57.25 & 76.3 & 67.15 & 6.85 & 72.66 & 2.92 & 70.22 & 4.28 & 58.56 & 0.80 \\
\hline 16 & Acidity & $\mathrm{mg} / \mathrm{lit}$ & 3.4 & 5.65 & 4.37 & 0.65 & 5.16 & 0.35 & 4.27 & 0.16 & 3.7 & 0.22 \\
\hline 17 & Phosphate & $\mathrm{mg} / \mathrm{lit}$ & 0.07 & 1.92 & 0.70 & 0.58 & 0.87 & 0.15 & 1.13 & 0.66 & 0.11 & 0.03 \\
\hline 18 & Nitrate & $\mathrm{mg} / \mathrm{lit}$ & 0.21 & 1.11 & 0.61 & 0.33 & 0.36 & 0.13 & 0.94 & 0.15 & 0.53 & 0.33 \\
\hline 19 & Sulphate & $\mathrm{mg} / \mathrm{lit}$ & 16.65 & 23.1 & 19.84 & 2.23 & 20.75 & 1.42 & 21.53 & 1.50 & 17.23 & 0.41 \\
\hline 20 & Chloride & $\mathrm{mg} / \mathrm{lit}$ & 4.5 & 7.1 & 5.92 & 0.89 & 4.77 & 0.31 & 6.57 & 0.39 & 6.42 & 0.41 \\
\hline
\end{tabular}


Dissolved oxygen is fluctuates seasonally. Most of the aquatic animals and plants are very sensitive to the dissolved oxygen. Temperature, light, turbidity also fluctuate the concentration of dissolved oxygen. If it is decline then survival rate of animals and plants also decline. Benthic organisms are adapted to the low concentration of water due to which they can survive in concentration of dissolved oxygen. More oxygen concentration in water indicates the good quality of water (Welch, P.S., 1952). The minimum average of dissolved oxygen $(5.71, \pm 0.1)$ was recorded in summer and maximum average of dissolved oxygen $(6.41, \pm 0.29)$ in monsoon as compared to the annual average of dissolved oxygen $(5.47, \pm 0.48)$. Low temperature in monsoon and winter than summer, leads to presence of high dissolved oxygen (Prasad B. N. and Manjula S., 1980,Zutshi D.P. and Vass K.K., 1978). Like dissolved oxygen, carbon dioxide is also play an important role in respiration and photosynthesis process. Generally more dissolved free carbon dioxide occurs in water body with large vegetation and dead and debris material. It is indirectly proportional to the dissolved oxygen as if there is high dissolved oxygen then there is low free carbon dioxide and vice versa. The minimum average of free carbon dioxide (5.04, \pm 0.22 ) was recorded in winter and maximum average of free carbon dioxide $(6.12, \pm 0.31)$ in summer as compared to the annual average of free carbon dioxide $(5.58, \pm 0.52)$ (Kaushik S. and Saksena D.N., 1991).

Alkalinity of surface water is mainly a function of carbonate, bicarbonate and hydroxide content and it is taken as an indication of the concentration of these constituents. The acceptable limit of Total Alkalinity in drinking water should not be more than $200 \mathrm{mg} / \mathrm{l}$ (BIS, 2012). Minimum alkalinity $(58.56, \pm 0.80)$ and maximum alkalinity $(72.66, \pm 2.92)$ respectively noted in winter and summer as compared to the annual average of alkalinity $(67.15, \pm 6.86)$.

Strong mineral acids, weak acids such as carbonic and acetic and hydrolyzing salts such as aluminium sulphates or iron may contribute to the measured acidity. Acids also contribute to corrosiveness and influences chemical speciation, biological processes, and chemical rates. It also reflects change in the quality of the source of water (AWWA-APHA., 2005). The low acidity $(3.7, \pm 0.22)$ was recorded in winter and maximum acidity $(5.16, \pm 0.35)$ in summer. The acidity was mostly decline in winter and increase in summer as photosynthesis uses up dissolved carbon dioxide.

Phosphorous is very essential nutrient as all living organisms require phosphate to make DNA and ATP. Animals easily meet their phosphate needs by eating other living things. Plants absorb phosphate from ground and rocks. The minimum average of phosphate $(0.11, \pm 0.04)$ was recorded in winter and maximum average of phosphate $(1.14, \pm 0.69)$ in monsoon as compared to the annual average of phosphate $(0.71, \pm 0.59)$. Phosphate mostly increases during monsoon due to increase in algal bloom and surface run-off while decreases in summer due to decrease in algal bloom and less vegetation in water (Welch, P.S., 1952).

Nitrate is an important source of nitrogen for plant and animal life. Animal matter, human and animal waste, household septic systems and fertilizers are the common sources of nitrogen. Excess nitrogen in drinking water has been found to cause methenoglobinemia or Blue Baby Syndrome (Fewtrell, L. 2004). The minimum average of nitrate $(0.36, \pm 0.13)$ was recorded in summer and maximum average of nitrate $(0.94, \pm 0.16)$ in monsoon as compared to the annual average of nitrate $(0.61, \pm 0.33)$. Nitrate mostly increases during monsoon due to increase in vegetation and surface run-off which include fertilizers while decreases in summer due to decrease in vegetation and surface run-off in water (Chatwal G.R.,1996, Das A.K.,1989 and Pande P.C. et.al., 1969).

Sulphates occur naturally in numerous minerals, including Epsomite $\left(\mathrm{MgSO}_{4} 7 \mathrm{H}_{2} \mathrm{O}\right), \quad$ Gypsum $\left(\mathrm{CaSO}_{4} 2 \mathrm{H}_{2} \mathrm{O}\right)$, Barite $\left(\mathrm{BaSO}_{4}\right)$. The reversible inter conversion of Sulphate and Sulphide in the natural environment is known as the 'sulphur cycle'. The EPA secondary Drinking Water Regulations recommend a maximum concentration of $250 \mathrm{mg} / \mathrm{l}$. Minimum average of sulphate $(17.24, \pm 0.41)$ and maximum average of sulphate $(21.54, \pm 1.51)$ in monsoon observed in lake water as compared to the annual average of sulphate $(19.84, \pm 2.23)$. Sulphate mostly increases during monsoon due to surface run-off which include fertilizers while decreases in summer due to decrease in surface run-off in water (Kaur H.et.al, 1996).

Chloride concentrations vary considerably according to the mineral content of the earth in any given area. Chlorides are dissolved from rock and soils The minimum average of chloride $(4.77, \pm 0.31)$ maximum average of chloride $(6.57, \pm 0.4)$ in Summer and monsoon respectively as compared to the annual average of chloride $(5.92, \pm 0.9)$. Chloride mostly increases during monsoon due to surface runoff (AWWA-APHA., 2005).

\section{Macrozoobenthos:}

Benthic organisms play a very important role in the ecosystems. Depending upon the size they are mainly categorized into three types- Macrozoobenthos, Meiozoobenthos and Microzoobenthos (Mare M.F., 1942). The influence of benthic organisms varies according to the quality and quantity of water body 
Table 3: Total number of macrozoobenthos (N/M $)$ observed during two year (Feb. 2012 to Jan. 2014)

\begin{tabular}{|c|c|c|c|c|c|c|c|c|c|c|c|c|}
\hline \multirow{2}{*}{ Class, Order \& Family } & \multicolumn{4}{|c|}{ SUMMER (N/M²) } & \multicolumn{4}{|c|}{ MONSOON (N/M²) } & \multicolumn{4}{|c|}{ WINTER (N/M²) } \\
\hline & Feb & Mar & Apr & May & Jun & Jul & Aug & Sep & Oct & Nov & Dec & Jan \\
\hline C- Oligochaeta & 377.78 & 311.11 & 155.56 & 44.44 & 111.11 & 266.67 & 244.44 & 377.78 & 355.56 & 400.00 & 311.11 & 244.44 \\
\hline F- Tubificidae & 222.22 & 155.56 & 88.89 & 0.00 & 44.44 & 155.56 & 133.33 & 200.00 & 177.78 & 222.22 & 177.78 & 133.33 \\
\hline F- Lumbricidae & 155.56 & 155.56 & 66.67 & 44.44 & 66.67 & 111.11 & 111.11 & 177.78 & 177.78 & 177.78 & 133.33 & 111.11 \\
\hline C- Hirudinea & 88.89 & 66.67 & 22.22 & 0.00 & 22.22 & 66.67 & 111.11 & 133.33 & 88.89 & 133.33 & 88.89 & 111.11 \\
\hline C- Arachnida & 88.89 & 66.67 & 22.22 & 0.00 & 44.44 & 88.89 & 111.11 & 111.11 & 133.33 & 155.56 & 111.11 & 111.11 \\
\hline C- Crustacea & 44.44 & 22.22 & 0.00 & 0.00 & 44.44 & 88.89 & 111.11 & 66.67 & 88.89 & 44.44 & 66.67 & 44.44 \\
\hline C- Insecta & 444.44 & 266.67 & 177.78 & 22.22 & 244.44 & 333.33 & 711.11 & 666.67 & 533.33 & 555.56 & 400.00 & 511.11 \\
\hline O- Odonata & 155.56 & 88.89 & 22.22 & 0.00 & 111.11 & 133.33 & 222.22 & 244.44 & 200.00 & 222.22 & 133.33 & 155.56 \\
\hline O- Diptera & 177.78 & 44.44 & 88.89 & 0.00 & 66.67 & 200.00 & 288.89 & 266.67 & 288.89 & 288.89 & 244.44 & 244.44 \\
\hline F- Culicidae & 66.67 & 22.22 & 44.44 & 0.00 & 22.22 & 44.44 & 111.11 & 88.89 & 111.11 & 111.11 & 88.89 & 44.44 \\
\hline F- Culicidae & 44.44 & 0.00 & 0.00 & 0.00 & 44.44 & 88.89 & 66.67 & 111.11 & 88.89 & 44.44 & 66.67 & 88.89 \\
\hline O- Hemiptera & 111.11 & 133.33 & 66.67 & 22.22 & 66.67 & 155.56 & 200.00 & 155.56 & 44.44 & 44.44 & 22.22 & 111.11 \\
\hline F- Nepidae & 66.67 & 66.67 & 44.44 & 0.00 & 44.44 & 88.89 & 111.11 & 66.67 & 44.44 & 0.00 & 22.22 & 66.67 \\
\hline F - Nepidae & 44.44 & 66.67 & 22.22 & 22.22 & 22.22 & 66.67 & 88.89 & 88.89 & 0.00 & 44.44 & 0.00 & 44.44 \\
\hline C-Gastropoda & 488.89 & 288.89 & 155.56 & 44.44 & 133.33 & 355.56 & 444.44 & 533.33 & 577.78 & 466.67 & 488.89 & 444.44 \\
\hline F-Viviparidae & 200.00 & 133.33 & 66.67 & 44.44 & 0.00 & 111.11 & 155.56 & 177.78 & 155.56 & 111.11 & 133.33 & 155.56 \\
\hline F-Thiaridae & 88.89 & 44.44 & 0.00 & 0.00 & 44.44 & 88.89 & 88.89 & 133.33 & 111.11 & 88.89 & 133.33 & 88.89 \\
\hline F-Lymnaeidae & 111.11 & 66.67 & 44.44 & 0.00 & 44.44 & 66.67 & 111.11 & 88.89 & 133.33 & 88.89 & 88.89 & 111.11 \\
\hline F-Pachilidae & 88.89 & 44.44 & 44.44 & 0.00 & 44.44 & 88.89 & 88.89 & 133.33 & 177.78 & 177.78 & 133.33 & 88.89 \\
\hline C-Bivalvia & 200.00 & 133.33 & 66.67 & 0.00 & 200.00 & 266.67 & 311.11 & 377.78 & 311.11 & 377.78 & 288.89 & 266.67 \\
\hline F-Unionidae & 66.67 & 44.44 & 22.22 & 0.00 & 44.44 & 88.89 & 88.89 & 133.33 & 88.89 & 133.33 & 88.89 & 88.89 \\
\hline F-Unionidae & 88.89 & 44.44 & 44.44 & 0.00 & 88.89 & 88.89 & 88.89 & 133.33 & 155.56 & 111.11 & 111.11 & 88.89 \\
\hline F- Unionidae & 44.44 & 44.44 & 0.00 & 0.00 & 66.67 & 88.89 & 133.33 & 111.11 & 66.67 & 133.33 & 88.89 & 88.89 \\
\hline Total Number of species $\left(\mathrm{N} / \mathrm{M}^{2}\right)=$ & 1733.33 & 1155.56 & 622.22 & 111.11 & 800.00 & 1622.22 & 2044.44 & 2266.67 & 2088.89 & 2133.33 & 1755.56 & 1733.33 \\
\hline
\end{tabular}

ISSN: 2456-1878

https://dx.doi.org/10.22161/ijeab.64.14 
Table 4: Statistical analysis of Macrozoobenthos (N/M²) observed during two years (Feb. 2012 to Jan. 2014)

\begin{tabular}{|c|c|c|c|c|c|c|c|c|c|c|c|c|c|}
\hline Class, Order \& Family & Genus \& Species & A-Avg. & S-Avg. & M-Avg. & W-Avg. & A.SD & S-SD & M-SD & W-SD & A-Total & S-Total & M-Total & W-Total \\
\hline C-Oligochaeta & $\longrightarrow$ & 266.67 & 222.22 & 250.00 & 327.78 & 108.49 & 130.53 & 94.77 & 57.47 & 3200.00 & 888.89 & 1000.00 & 1311.11 \\
\hline F-Tubificidae & Limnodrillushoffemeistry & 142.59 & 116.67 & 133.33 & 177.78 & 65.71 & 82.21 & 56.66 & 31.43 & 1711.11 & 466.67 & 533.33 & 711.11 \\
\hline F-Lumbricidae & Lumbricus variegatus & 124.07 & 105.56 & 116.67 & 150.00 & 44.87 & 50.61 & 39.67 & 28.87 & 1488.89 & 422.22 & 466.67 & 600.00 \\
\hline C-Hirudinea & Hirudinaria granulosa & 77.78 & 44.44 & 83.33 & 105.56 & 42.07 & 35.14 & 42.67 & 18.43 & 933.33 & 177.78 & 333.33 & 422.22 \\
\hline C-Arachnida & Hydracarinasp. & 87.04 & 44.44 & 88.89 & 127.78 & 43.94 & 35.14 & 27.22 & 18.43 & 1044.44 & 177.78 & 355.56 & 511.11 \\
\hline C-Crustacea & Gelasimussp. & 51.85 & 16.67 & $\mathbf{7 7 . 7 8}$ & 61.11 & 33.13 & 18.43 & 24.85 & 18.43 & 622.22 & 66.67 & 311.11 & 244.44 \\
\hline C-Insecta & $\longrightarrow$ & 405.56 & 227.78 & 488.89 & 500.00 & 196.29 & 152.65 & 203.06 & 59.84 & 4866.67 & 911.11 & 1955.56 & 2000.00 \\
\hline O-Odonata & Dragonfly nymph \& Damselfly nymph & 140.74 & 66.67 & $\mathbf{1 7 7 . 7 8}$ & $\mathbf{1 7 7 . 7 8}$ & 73.89 & 60.86 & 56.66 & 35.14 & 1688.89 & 266.67 & 711.11 & 711.11 \\
\hline O-Diptera & & 183.33 & $\mathbf{7 7 . 7 8}$ & 205.56 & 266.67 & 101.48 & 65.73 & 86.60 & 22.22 & 2200.00 & 311.11 & 822.22 & 1066.67 \\
\hline F-Culicidae & Culex larvae & 62.96 & 33.33 & 66.67 & 88.89 & 37.22 & 24.85 & 35.14 & 27.22 & 755.56 & 133.33 & 266.67 & 355.56 \\
\hline F-Culicidae & Anopheles larvae & 53.70 & 11.11 & 77.78 & 72.22 & 36.80 & 19.25 & 24.85 & 18.43 & 644.44 & 44.44 & 311.11 & 288.89 \\
\hline F-Tabanidae & Tabanussp. & 66.67 & 33.33 & 61.11 & 105.56 & 41.57 & 24.85 & 39.67 & 18.43 & 800.00 & 133.33 & 244.44 & 422.22 \\
\hline O-Hemiptera & & 94.44 & 83.33 & 144.44 & 55.56 & 56.02 & 42.67 & 48.43 & 33.33 & 1133.33 & 333.33 & 577.78 & 222.22 \\
\hline F-Nepidae & Nepasp. & 51.85 & 44.44 & 77.78 & 33.33 & 31.86 & 27.22 & 24.85 & 24.85 & 622.22 & 177.78 & 311.11 & 133.33 \\
\hline F-Nepidae & Ranatraelongata & 42.59 & 38.89 & 66.67 & 22.22 & 29.34 & 18.43 & 27.22 & 22.22 & 511.11 & 155.56 & 266.67 & 88.89 \\
\hline C-Gastropoda & $\longrightarrow$ & 368.52 & 244.44 & 366.67 & 494.44 & 166.66 & 165.55 & 148.66 & 50.61 & 4422.22 & 977.78 & 1466.67 & 1977.78 \\
\hline F-Viviparidae & Vivipara bengalensis & 120.37 & 111.11 & 111.11 & 138.89 & 55.52 & 60.86 & 68.49 & 18.43 & 1444.44 & 444.44 & 444.44 & 555.56 \\
\hline F-Thiaridae & Melanoidesstriatella & 75.93 & 33.33 & 88.89 & 105.56 & 42.99 & 36.85 & 31.43 & 18.43 & 911.11 & 133.33 & 355.56 & 422.22 \\
\hline F-Lymnaeidae & Lymnealutiola & 79.63 & 55.56 & 77.78 & 105.56 & 35.67 & 40.06 & 24.85 & 18.43 & 955.56 & 222.22 & 311.11 & 422.22 \\
\hline F-Pachilidae & Fanusater & 92.59 & 44.44 & 88.89 & 144.44 & 52.77 & 31.43 & 31.43 & 36.85 & 1111.11 & 177.78 & 355.56 & 577.78 \\
\hline C-Bivalvia & $\longrightarrow$ & 233.33 & 100.00 & 288.89 & 311.11 & 113.13 & 74.54 & 64.79 & 41.57 & 2800.00 & 400.00 & 1155.56 & 1244.44 \\
\hline F-Unionidae & Lamellidensmarginalis & 74.07 & 33.33 & 88.89 & 100.00 & 38.84 & 24.85 & 31.43 & 19.25 & 888.89 & 133.33 & 355.56 & 400.00 \\
\hline F-Unionidae & Lamellidenscorreanus & 87.04 & 44.44 & 100.00 & 116.67 & 40.02 & 31.43 & 19.25 & 24.22 & 1044.44 & 177.78 & 400.00 & 466.67 \\
\hline F-Unionidae & Parreysiacorrugata & 72.22 & 22.22 & 100.00 & 94.44 & 42.67 & 22.22 & 24.85 & 24.22 & 866.67 & 88.89 & 400.00 & 377.78 \\
\hline
\end{tabular}

Avg = Annual Average, S. Avg = Summer Average, M. Avg = Mansoon Average, W. Avg = Winter Average, SD= Standard Deviation 
Other than food for different pray, different types of benthic organisms have different role in ecosystems like bio indicators of water. During qualitative analysis 19 species of macrozoobenthos from Phylum-Annelida, Arthropoda and Mollusca were noted during the collection from all sites of Kunghada Bandh.

After quantitative analysis, minimum average of total macrozoobenthos $\left(905.56 \mathrm{~N} / \mathrm{M}^{2}\right)$ was recorded in summer and maximum average of total macrozoobenthos $\left(1927.18 \mathrm{~N} / \mathrm{M}^{2}\right)$ in winter as compared to the annual average of total macrozoobenthos $\left(1505.56 \mathrm{~N} / \mathrm{M}^{2}\right)$. Seasonal fluctuation of macrozoobenthos was observed due to quantity of water and depth of water in lake (Dutta S.P. et.al.,2000, Rosenberg D.M. andResh W.H., 1992).

During the study period three species of annelids were found i.e. Limnodrillus hoffemeisteri, Lumbricus variegatus and Hirudinaria granulose. Minimum annelids (266.67 N/M ${ }^{2}$ ) were recorded in summer while maximum (433.33 N/M ${ }^{2}$ ) in winter as compared to the annual average of Annelids (344.44 N/M ${ }^{2}$ ) which covering 29.91 $\%$ out of the total number of macrozoobenthos (Chapman P.M. et.al., 1982 and Glowacka I., et.al., 1976).Oligochaeta mostly prefer organically rich environment and remain dominated in severally polluted conditions. Oligochaeta are adapted to every kind of water and are found in vegetation, algal bloom, in floating rotting material and bottom mud. During investigation, annelids observed more in monsoon and winter than summer (Wetzel, R.G., 1975).

Arthropods are the largest phylum with a great diversity. Total 9 species of arthropods were observed from lake i.e. Hydracarina sp., Gelasimus sp, Dragonfly sp, Damselfly sp, Culex sp, Anopheles sp, Tabanus sp., Nepa cinerea and Ranatra elongata. During the study minimum population (288.89 N/M ${ }^{2}$ ) of arthropods were recorded in summer while maximum (694.44 N/M $\left.{ }^{2}\right)$ in monsoon season. Arthropods were covering $37.07 \%$ out of the total macrozoobenthos population. The seasonal fluctuation in arthropod population was observed due to quantity of water and depth of water. The aquatic insects are known to have strong relationship with water fluctuations (Ebert T.A. and Balko., 1987). As hardness, carbonates and bicarbonates increase in water the stages of developmental stages to observed minimum (Fraser F.C.,1934 and Lonkar S.S. et.al., 2014). Dipterans noted more when dissolved oxygen increases with decreasing temperature. Such type of favourable conditions affects on population of dipterans (Kodarkar M.S., 1995 and Mathew P.M., 1978).Hemiptera are mainly found at the $S_{3}$ and $S_{4}$ sites of lake as these sites were received maximum runoff contains organic substances (Kaushik S. and Saksena D.N., 1991).
Phylum Mollusca is the second largest phylum with great diversities and species richness, basically gastropoda and bivalvia are the only two classes represented the molluscan in fresh water bodies (Shanmugam A. and Vairamani S., 2005). In all 7 species (4 gastropodes and 3 bivalves) were recorded from this fresh water aquatic ecosystem i.e. Vivipara bengalensis, Melania striatella, Fanus ater, Lymnea luteola, Parreysia corrugata, Lamellidens marginalis, and Lamellidens correanuI. Minimum population of Molluscan $\left(344.44 \mathrm{~N} / \mathrm{M}^{2}\right)$ was recorded in summer and maximum $\left(805.56 \mathrm{~N} / \mathrm{M}^{2}\right)$ in monsoon as compared to the annual average of Molluscan $\left(601.85 \mathrm{~N} / \mathrm{M}^{2}\right)$ covering $40.02 \%$ out of the total population of macrozoobenthos of lake. As the $\mathrm{pH}$ of lake water not acidic the population of mollusca is in fair quantity (Apte D., 1988). With the increased volume of water the population shows more during rainy season (Bath K.S. et.al, 1999 and Tijare R.V., 2012).

\section{CONCLUSION}

Various physic-chemical parameters play an important role in water quality as well as diversity and richness of organisms. Mostly temperature is a very important factor. Others factors like $\mathrm{pH}$, Dissolved oxygen, free $\mathrm{CO} 2$, Suspended solids, etc. also affect the frequency of macrozoobenthos. It was mostly observed macrozoobenthos found very less in summer season than monsoon and winter season. Phylum Arthropoda were dominated among the all group which is followed by mollusca and then annelids.

\section{ACKNOWLEDGEMENT}

Authors are very much thankful to the Director, Institute of Science, Nagpur (Maharashtra) for providing necessary laboratory facilities for this work.

\section{REFERENCES}

[1] ApteD.(1988), The book of Indian shells, Bombay Natural History Society, Mumbai; Pp. 115.

[2] AWWA-APHA. (2005), Standard methods for the examination of water and wastewater. American PublicHealthAssociation, Washington; DC, $21^{\text {st }}$ Ed.

[3] Bath K.S., Kaur H., Dhillon S.S.(1999), Correlation of molluses with physico-chemical factors at HarikeReservoir(Punjab). Indian Journal of Environmental Science, 3: 159-163.

[4] BIS. (2012), Standards for water for drinking and other purposes. Bureau of Indian Standards, New Delhi, pp. 1-12.

[5] Chapman P.M., Farrel M.A., BrinkhurstR.O.(1982), Relative tolerance of selected aquatic oligochaetes to 
individual pollutants and environmental factors. Aquatic Toxicology, 2: 47-67.

[6] Chatwal G.R.(1996),Encyclopedia of Environmental Pollution. Amol publications Pvt. Ltd. New Delhi, India,pp. 2212.

[7] Cole G.A.(1994), Textbook of Limnology, Waveland press $4^{\text {th }}$ Ed, pp. 412.

[8] Das A.K.(1989), Handbook of limnology and water pollution with practical methodology. South Asian publishers. Rt. Ltd. NewDelhi, 1989. pp. 174.

[9] Dubey M.A., Tiari K., Ujjaina N.C. (2013), The study of Physico-chemical properties of Shahapur Lake Bhopal (I), InternationalJournal of Advanced Research, 1(8): 158-164.

[10] Dutta S.P., Malhotra S.Y.R., Sharma K.K., Sinha K. (2000), Dial variations in physico-chemical parameters of water in relationtomacrobenthic invertebrates in some pool adjacent to the River Tawi, Nagorta Bye pass, Jammu. Journal ofEnvironmental Zoology,14:13-24.

[11] Ebert T.A., Balko. (1987), Seasonal changes in the invertebrate community of small shallow ephemeral pans at Bain's Vlei, South Africa. Hydrobiologia,, 317(1): 54-64.

[12] FewtrellL.(2004),Drinking-Water Nitrate, Methemoglobinemia, and Global Burden of Disease: A Discussion. Environ Health Perspect,112 (14): 1371-1374.

[13] Fraser F.C..(1934), The fauna of British India, including Ceylon and Burma.Odanata, Vol 2, Taylor and Francis, London,pp. 442.

[14] Glowacka I, Sozkaand G.J., Sozkak, H.(1976), Invertebrates associated with macrophytes, pp. 97-122.

[15] Kaur H., Dhillon S.S., Bath K.S., ManderG.(1996), Analysis of the elements polluting River Ghaggara in the region of Punjab. Journal of Environment \& pollution, 1996, 3 (2): 65-68.

[16] Kaushik S., Saksena D.N. (1991), Physico-chemical factors and the aquatic insect density of a pond receiving cotton mill effluentat Gwalior. Indian Journal of Ecology, 16 (1): 64-67.

[17] Karim L.R., Nair M..S.V, Williams E.S. (2012),MuncipalSolid Waste dumping on Ashtamudi lake, Kollam, Kerala - An overview, The Ecoscan, 1: 105-110.

[18] Kodarkar M.S. (1995),Conservation of lakes with special reference to five water bodies in and around Hyderabad. Indian Association of Aquatic Biologists (IAAB), Hyderabad, Publication No. 3, pp. 82-86.

[19] Kumar B.M., Katti R.J., Moorthy K.S.V., D'souzaR.K..(2004), Macrobenthos in relation to sediment characteristics of near shorewaters of Chitrapur, west coast of India receiving industrial effluents. Asian Fishery Science, 2004, 17:21-28.

[20] Lonkar S.S., Kedar G.T., Kotangale J.P. (2014), Macrozoobenthic diversity of three urban lakes of Nagpur, Central India. International Journal of Advanced Research, 2(4): 1082-1090.

[21] Mare M.F.(1942), A study of marine benthic community with special reference to the micro-organisms. U. K. Journal of MarineBiology, 25: 517-554.

[22] Mathew P.M. (1978), Limnological Investigation on the plankton of Govindgarh lake and its correlation withphysicochemical factors. Proceedings of Seminar on Economic Fisheries Freshwater reservoir,1978, pp. 37-46.

[23] Needham J.G. (1962), A guide to the study of freshwater biology, McGraw-Hill Science Engineering, $5^{\text {th }}$ Edition, pp. 108.

[24] Pande P.C., Suryanarayana K., Deshpande G.G. (1969), Seasonal changes in physical and chemical conditions of some Indian Lake.Mineral research, 2: 20-28.

[25] Pawar S., Sonawane S. (2011), Water quality index of Kanher Dam of Satara District (M. S.) India. International Journalof Biosciences, 1(6): 81-87.

[26] Puri P.J., Yenkie M.K.N., Battalwar D.G., Gandhare N.V., Dhanorkar D.B. (2010), Study and interpretation of physicochemicalcharacteristic of lake water quality in Nagpur city (India). Rasayan Journal of Chemistry, 3(4): 800-810.

[27] Prasad B.N., Manjula S. (1980), Ecological study of Blue green algae in river Gomati. Indian Journal of Environmental Health, 22: 151-168.

[28] Rajanna A.H., Belagalli, S.L.(2011), Assessment of Seasonal Variation of Physico-chemical Profile of Kabini River, Nanjangud, Mysore, Karnataka. The Ecoscan, 5 (4): pp. 147-151.

[29] Rosenberg D.M., Resh W.H. (1992), Freshwater Biomonitoring and Benthic Macro-invertebrates. Cahpman\& Hall publications, New York,London, pp.488.

[30] Santhanam R.,Velayutham P., Jegatheesan G. (1989), A manual of freshwater ecology, Daya Publishing House, Delhi. India,pp.109.

[31] Shanmugam A., Vairamani S. (2005), Mollusca in mangroves: A case study, Centre of advanced studies in Marine biology, Annamalai University,pp. 371.

[32] Shinde S.K., Pathan T.S., Raut K.S., More P.R., Sonawane D.L. (2010), Seasonal variation in HarsoolSawangi Dam,District Aurangabad, India, The Ecoscan, 4(1): 37-44.

[33] Sukund B.N., Patil H.S. (2004), Water quality assessment for lake of Belagum (Karnataka) with special reference to zooplankton, Journal of Environmental Biology, 25(1): 99102.

[34] Tijare R.V. (2012), Biodiversity of Mollusca presents in some lentic bodies of Gadchiroli District, M. S. (India), Bionanofrontier,5 (2): 55-56.

[35] Tonapi G.T. (1980), Freshwater animal of India: An ecological approach, Oxford and IBH Publishing company, New Delhi, pp. 341.

[36] Trivedi R.K., Goel P.K. (1984), Chemical and biological methods for water pollution studies. Enviromedia publication, Karad, pp. 251.

[37] Welch P.S. (1952), Limnology Revised edition. McGraw Hill, New York., pp 538.

[38] Wetzel R.G. (1975), Limnology, W. B. Saunders Co. Philadelphia, pp.743.

[39] Wilson P.C. (2010), Water quality notes: Water clarity (turbidity, suspended solids, and colour), pp.1-8.

[40] Zutshi D.P., Vass K.K. (1978), Limnological studies on Dal Kake. Chemical features, Indian Journal of Ecology,5: 9097. 